\title{
FIRST SYMPOSIUM IN APPLIED MATHEMATICS
}

The first annual Symposium in Applied Mathematics of the American Mathematical Society was held at Brown University, Providence, Rhode Island, Saturday to Monday, August 2-4, 1947. The subject of the Symposium was Non-linear problems in mechanics of continua. The following 265 persons, including 143 members of the Society, registered:

C. R. Adams, R. B. Adams, E. J. Akutowicz, H. J. Ansoff, R. C. Archibald, D. L. Arenberg, G. M. Arsove, M. G. Arsove, J. L. Barnes, I. L. Battin, Louis Bauer, Leonard Becker, Reinier Beeuwkes, J. C. Bell, A. I. Bellin, Richard Bellman, A. A. Bennett, Stefan Bergman, Lipman Bers, Garrett Birkhoff, Gertrude Blanch, B. C. Blanco, W. E. Bleick, A. D. Booth, L. R. Boyle, F. R. Brand, P. J. Bray, R. C. Briant, S. R. Brinkley, K. H. Britten, J. H. Bronzo, Felix Buckens, A. S. Campbell, R. M. Canning, E. W. Cannon, M. E. Carlen, G. F. Carrier, K. V. Casey, T. E. Caywood, A. I. Chalfant, H. A. Cheilek, P. P. Chen, Herman Chernoff, Peter Chiarulli, Charles Chin, W. S. Clement, R. F. Clippinger, Nathaniel Coburn, H. G. Cohen, Charles Concordia, D. P. Congdon, C. H. Coogan, E. A. Cook, John Crawford, J. E. Crawford, L. L. Cronvich, C. W. Crook, W. J. R. Crosby, J. M. Crowley, C. R. DePrima, J. B. Díaz, G. H. Dixon, C. L. Dolph, M. F. Dowell, W. G. Driscoll, D. C. Drucker, R. P. Eddy, Franz Edelman, Nat Edmonson, F. E. Ehlers, H. W. Emmons, O. C. Enikeieff, H. J. Ettlinger, Herbert Federer, Morton Finston, F. G. Fisher, J. R. Foote, R. M. Foster, F. H. Fowler, A. H. Fox, J. C. Freeman, Bernard Friedman, K. O. Friedrichs, D. L. Fuller, C. A. Garabedian, P. R. Garabedian, B. E. Gatewood, Abe Gelbart, J. H. Giese, Joseph Gillis, R. E. Gilman, Sydney Goldstein, Rosa Goldstein, H. H. Goode, H. J. Greenberg, H. R. J. Grosch, A. R. Gruber, Harold Gumbel, Shirley Gumbel, N. S. Hall, G. H. Handelman, Duncan Harkin, M. G. Harrison, G. K. Hartman, G. E. Hay, L. B. Hedge, G. S. Heller, Joseph Hilsenrath, D. L. Holl, T. R. Hollcroft, D. F. Hornig, P. T. Hsu, E. M. Hull, L. C. Hutchinson, J. S. Isenberg, Fritz John, B. G. Johnston, Robert Kahal, E. L. Kaplan, Wilfred Kaplan, S. N. Karp, Stanley Katz, Sara Kaufman, C. E. Kerr, W. M. Kincaid, Bertram Klein, Knud-Endre Knudsen, B. O. Koopman, G. L. Kreezer, J. A. Krumhansl, M. Z. Krzywoblocki, C. F. Ksanda, Gustav Kuerti, Y. H. Kuo, S. H. Lachenbruch, O. E. Lancaster, H. G. Landau, Philip LeCorbeiller, Patrick Leehey, Lester Lees, Norman Levinson, Samuel Levy, Henry Lew, J. A. Lewis, P. A. Libby, C. C. Lin, R. B. Lindsay, D. P. Ling, J. N. B. Livingood, Charles Loewner, A. N. Lowan, R. D. Luce, S. W. McCuskey, S. S. McNeary, J. K. L. MacDonald, D. P. MacDougall, C. E. Mack, Paul Maeder, L. E. Malvern, J. H. Marchant, W. T. Martin, R. C. Meacham, George Melrose, Irving Michelson, C. C. Miesse, R. B. Montgomery, Melvin Mooney, Morris Morduchow, H. H. Mostafa, Wolfe Mostow, M. M. Munk, F. D. Murnaghan, P. F. Nemenyi, E. N. Nilson, Lawrence Nilson, Yves Nubar, Lars Onsager, Isaac Opatowski, Elias Orshanson, C. J. Osborn, W. H. Pell, P. M. Pepper, A. D. Perry, F. V. Pohle, Harry Polachek, Hillel Poritsky, William Prager, R. C. Prim, M. H. Protter, Gordon Raisbeck, Mina Rees, Eric Reissner, H. J. Reissner, J. A. Rice, J. M. Richardson, R. G. D. Richardson, J. K. Riess, R. F. Rinehart, Jacques Rivaud, R. J. Rivlin, R. E. Roberson, R. C. Roberts, H. P. Robertson, S. I. Rubinow, B. T. Ruley, J. P. Russell, Edward Saibel, Charles Saltzer, 
J. A. Saur, S. A. Schaaf, A. B. Schacknow, M. M. Schiffer, G. V. Schliestett, R. W. Schmied, R. N. Schwartz, W. R. Sears, C. H. W. Sedgewick, R. J. Seeger, Hyman Serbin, D. M. Seward, F. S. Shaw, S. F. Shen, W. L. Sherman, Marlow Sholander, S. S. Shu, D. N. Silver, David Singer, D. G. Skillman, C. V. L. Smith, Harold E. Smith, D. E. Spencer, V. E. Spencer, F. D. Stockton, J. J. Stoker, Henry Stommel, E. G. Straus, E. W. Suppiger, P. S. Symonds, J. L. Synge, A. H. Taub, Edward Temple, Feodor Theilheimer, G. B. Thomas, A. N. Tifford, C. B. Tompkins, Deonisie Trifan, Rohn Truell, C. A. Truesdell, J. W. Tukey, M. P. Tulin, Judith Ullman, Ernst Weber, J. V. Wehausen, Herschel Weil, Alexander Weinstein, E. T. Welmers, D. W. Western, F. J. Weyl, Alice Winzer, H. A. Wood, Dorothy Wrinch, A. W. Wundheiler, C. S. Yih, A. T. Yu, P. W. Zettler-Seidel.

The Symposium was cosponsored by the American Institute of Physics, the American Society of Mechanical Engineers, and the Institute of Aeronautical Sciences.

The dormitories of Brown University and the Faunce House Cafeteria and Lounges were available to those attending the Symposium.

An address of welcome was given at 10:00 A.M. Saturday at the opening session of the Symposium by Dean S. T. Arnold of Brown University.

Professor J. L. Synge, Chairman of the Committee on Applied Mathematics, presided at the opening session. Following the address of welcome, Professor Synge gave a brief review of the plans for Symposia in Applied Mathematics of which this was the first.

The ladies attending were conducted through Pendleton House on Saturday afternoon. Tea was served by the ladies of the Departments of Mathematics of Brown University in Pendleton House on Saturday afternoon and in John Carter Brown Library on Sunday afternoon. At 4:15 P.M. Monday, there was an excursion to Newport with dinner at the Viking Hotel.

A photograph of those attending the symposium was taken Saturday on the steps of the John Carter Brown Library.

The four principal addresses given by invitation of the Committee on Applied Mathematics were as follows: at 10:00 A.M. Saturday, The foundations of the theory of elasticity by Professor F. D. Murnaghan of Johns Hopkins University; at 10:00 A.M. Sunday, Surface waves in shallow water by Professor J. J. Stoker of New York University; at 10:00 A.M. Monday, The edge effect in bending and buckling with large deflections by Professor K. O. Friedrichs of New York University; at 2:20 P.M. Monday, Non-linear problems in the theory of fluid motion with free boundaries by Professor Alexander Weinstein of Carnegie Institute of Technology.

The Symposium was divided into three morning and three afternoon sessions. At four of these sessions, the principal addresses were given, each followed by a discussion period. In addition, twenty-one 
twenty-minute papers were given. A group (usually three) of these papers in a certain field was followed by a half-hour discussion period.

The twenty-one papers were presented in the following order:

1. Samuel Levy: Large deflection theory for rectangular plates.

2. Eric Reissner: Remarks on finite deflections of elastic plates.

3. G. F. Carrier: On dynamic structural stability.

4. Hillel Poritsky: An approximate method of integrating the hodograph equations of a compressible fluid.

5. Lipman Bers: Some problems in two dimensional gas dynamics.

6. Stefan Bergman: Operator methods in the theory of compressible fluids.

7. C. L. Dolph and Nathaniel Coburn: The method of characteristics in three-dimensional steady supersonic flow of compressible fluids.

8. Isaac Opatowski: Stream lines of compressible and rotational flows.

9. S. R. Brinkley: Theory of the propagation of shock waves from cylindrical charges of explosive.

10. Harry Polachek and R. J. Seeger: On shock wave phenomena.

11. A. H. Taub: Some aspects of the interaction of shock waves in gases.

12. Sydney Goldstein: Singularities in the solution of the boundary layer equations at separation.

13. Lester Lees: Stability of the laminar boundary layer in a compressible fluid.

14. W. R. Sears: Some three-dimensional boundary layer flows.

15. C. C. Lin: Remarks on the spectrum of turbulence.

16. H. W. Emmons: A numerical treatment of the turbulence problem.

17. Y. H. Kuo: On the stability of transsonic flow.

18. Wilfred Kaplan: Numerical methods in the solution of problems of non-linear elasticity.

19. D. C. Drucker: Stress-strain relations for strain-hardening materials.

20. William Prager: Discontinuous solutions in the theory of plasticity.

21. Garrett Birkhoff: Recent applications of free boundary theory.

The two following papers were on the program but were not presented due to the absence of the authors:

Richard Courant: Methods of solving non-linear hyperbolic partial differential equations.

Arpad Nadai: Some remarks concerning the theory of the formation of surfaces of slip in plastic bodies.

The presiding officers at the sessions were, respectively: Professors 
J. L. Synge, Ernst Weber, Sydney Goldstein, H. P. Robertson, W. T. Martin, S. W. McCuskey, D. L. Holl and J. W. Tukey.

At the close of the Monday afternoon session, a resolution of thanks and appreciation to Brown University for its hospitality was read by Professor H. J. Ettlinger and unanimously approved.

The addresses and papers presented at the Symposium are to be published by the Society in a volume of the Proceedings of the First Symposium in Applied Mathematics.

William Prager, Secretary of the Committee on Applied Mathematics

T. R. HollCRofT, Associate Secretary of the Society 